\title{
Contributions of Trade Unionism to Sustainable Development: The Case of the IPLIDO-UTHGRA
}

\author{
María Susana Césari ${ }^{1}$, Johanna Maldovan Bonelli ${ }^{2}$, Mariana Russak ${ }^{1}$ and \\ Jörg Eggers ${ }^{1}$
}

\begin{abstract}
For several decades it has been internationally recognized the role of unions in promoting sustainable development goals, especially in its economic, social and cultural dimensions. While the commitment to free association, social dialogue and collective bargaining are some of the main aspects of their actions, trade union organizations also work in other key areas to achieve social justice, such as access to information, education, health and gender equity. The Institute for Equal Opportunities (IPLIDO) of the Union of Tourism, Hotel and Gastronomy Workers of the Argentine Republic (UTHGRA) is a paradigmatic case on this path. In order to ensure equal opportunities for all people (based on the equal participation of men and women in the labor, economic, political, cultural and family) the IPLIDO has carried out several actions aimed at: strengthen ties in the community; build networks among non-governmental organizations, trade unions and public institutions; promote gender equality; disseminate information and train in pressing issues such as addictions, grooming and gender violence; and participate in the design and implementation of laws and public policies, among others. This paper addresses the strategies and actions carried out by the IPLIDO since its creation -in 2006-, highlighting its interaction with the public sector, international and civil society organizations, in order to promote rights and values in the trade union sphere and the community in general.
\end{abstract}

\section{Introduction}

The problem of sustainability has been continuously addressed since the first debates around it began in the 1960's; as a response to the consequences triggered by capitalist production and consumption patterns established worldwide since the last quarter of the 20th century. Over the last decades, the notion of sustainability has been present in the development of public programs and public policies as well as in the goals of multilateral organizations. It has been the subject of international conventions and agreements. Among them, the 2030 Agenda -which has been in force since 2016- has established 17 Sustainable Development Goals (SDGs) with 169 targets adopted by 193 member states of the United Nations.

Trade unions are deeply involved in the 2030 Agenda at a national, regional and global level. Through their daily work in sustaining freedom of association, social dialogue and collective bargaining, as well as promoting decent working conditions, social protection systems and workers's rights, unions are essential institutions to achieving the SDGs.

Relevance of civil society organizations in terms of what they contribute to the effective achievement of this Agenda is reflected in SDG \#17. It states that: "A successful sustainable development agenda requires partnerships between governments, the private sector and civil society. These inclusive partnerships built upon principles and values, a shared vision, and shared goals that place people and the planet at the centre, are needed 
at the global, regional, national and local level" (UN, Goal 17 ). In other words, without the active participation of civil society, the SDGs and their goals can not be achieved.

The Institute for Equal Opportunities Tourism, a member of the Argentine Hotel and Culinary Workers Union [IPLIDO-UTHGRA] is an example of this path. From a trade union perspective, IPLIDO aims to guarantee equal opportunities for all workers, based on equal participation by men and women in the work, economic, political, cultural and family contexts. Its actions are based on a constant interaction between the state, the international community and the civil society in order to ensure the promotion of rights and values in the trade union field as well as in the local community.

Taking this into account, this article sets out to address the strategies and actions carried out by the IPLIDO since its foundation in 2006. Among them, we will focus on its interaction with the public sector and international and civil society organizations, as well as in the different actions carried out at the local level by the head office and the regional local offices. We will first present the main debates related to the notion of sustainability with special emphasis on its social dimension (given that this is the main area of IPLIDO intervention); so as to then be able to give an account of the main actions and strategies carried out by the Institute in pursuit of achieving equal opportunities and social justice.

\section{Social Dimension of Sustainability and Challenges for Trade Unionism}

The concept of sustainability emerged in the 1960s as an answer to global consequences of Second World War and the nuclear tests conducted in the context of the Cold War. As environmental issues became more important in the world, sustainability has been adopted as a global goal. This was the context that framed the United Nations Conference on the Human Environment was held in Stockholm in 1972. This was the first international conference aimed at discussing the state of the global environment and marked a turning point in the development of international environmental politics.

From then on, the social dimension was included as a central aspect taken into account in reflecting upon the notion of sustainability. The United Nations Commission on Environment and Development [UNCED], constituted in the late 1980s, published the Our Common Future Report (1987) -also known as the Brundtland Report- which established the need to consider the problem of development as a complex balance between the growth of wealth, social integration and environment protection. The Brundtland Report defined 'sustainable development' as the development that meets the needs of the present without compromising the future generations' ability to meet their own needs. Since then, diverse disciplines have included this concept in their theoretical frameworks, although not always with equivalent connotations.

Over the last thirty years of the twentieth century, debates around sustainable development, as well as the policies based on this approach, have emphasized the need to improve environmental legacy for future generations, setting the concern for a better quality of life (in social terms) aside as merely a means to achieve that goal. In this sense, the social dimension of sustainability has been limited to approaches focused on reducing poverty or limiting population growth. It was not until the turn of the millennium when the international community focused on increasing human capabilities 
and improving quality of life as a target for sustainable development, rather than as a means to achieve a more sustainable environment (Foladori, 2002).

The greater importance given to the social dimension of sustainability has not been accompanied, however, by a consensus on how to define it. On the contrary, a review of specialized literature shows that this is a concept in chaos, which, in turn, severely compromises its importance and utility (Vallance, Perkins \& Dixon, 2011). In this sense, "...social sustainability, as an independent dimension of sustainable development, and equally important as the economic or environmental dimension (United Nations 1993) still lacks broad recognition by scientists as well as by decision makers" (Omann \& Spangenberg, 2002, p. 3).

The lack of consensus on appropriate criteria for measuring and designing policies linked to social sustainability has led to a situation in which "each project derives its own set of indicators and criteria specific to the research question analysed, but rarely applicable on the macro level of societies' social sustainability" (Omann \& Spangenberg, 2002, p. 1).

Based on these statements, some authors argue that "...the concept sustainability should regain its original meaning of ecological sustainability [since] spreading to include society and the economy creates confusion, and, instead of supporting a noble cause, it has negative consequences, although people think that we are heading in a good direction" (Károly, 2011, p. 10).

On the other hand, other authors have outlined some useful definitions. Stephen Mckenzie (2004) suggests that "...social sustainability occurs when the formal and informal processes, systems, structures and relationships actively support the capacity of current and future generations to create healthy and liveable communities. Socially sustainable communities are equitable, diverse, connected and democratic and provide a good quality of life” (p. 20). As Gomaa and Sakr (2015) say, other scholars give a more in-depth analysis, identifying several aspects of social sustainability. Sachs (1999) recognizes a number of constituent elements such as social homogeneity, employment, equitable incomes and access to goods and services. He also highlihts the importance of political sustainability concerning democracy and human rights and cultural sustainability regarding the balance between external imposed change and continuity.

According to another perspective -that matches IPLIDO point of view- the University of Gävle suggests that "social and cultural sustainability concerns issues regarding people's opportunities to fulfil their potential. Depending on where in the world we live and at what stage in our lives we are, our needs look different. It may concern freedom of religion or finding balance in life in a developed society. It may concern the possibility to educate ourselves, or to provide for ourselves or to live in peace" (Löf, 2018). Spangenberg, Pfahl and Deller (2002) agree with them and state that social sustainability focuses on personal assets like education, skills, experience, consumption, income and employment, while institutional sustainability aims at interpersonal processes like democracy and participation (institutional mechanisms), distributional and gender equity (institutional orientations) or independent and plural sources of information (organizations). In this sense, we agree with Omann and Spangenberg (2002) in that "...institutional settings often provide the opportunity space for social sustainability to develop; as a certain overlap cannot be avoided institutional aspects will have to be taken into account when discussing social sustainability" (p. 2). It is mainly for this reason 
that social participation is one of the most interesting topics in the discussion on social sustainability. Participation is an indicator of democratic freedoms, equality in decisionmaking, and a key element in enhancing productive efforts (Foladori, 2002).

In terms of international policy, the heads of state and government of the 193 countries of the General Assembly of the United Nations adopted the current Agenda for Sustainable Development, which has been in force since January 1st 2016. This Agenda sought to expand the frameworks previously established by two complementary global processes: the United Nations Millennium Declaration and the Millennium Development Goals on the one hand, and the UN Conferences on Environment and Development on the other.

The novelty of the Sustainable Development Goals (SDGs) approach lies in the fact that, in addition to traditional development goals -such as ending poverty and hunger- they establish a wide range of economic, social and environmental goals from a human rights perspective.

Thus, "the goals and targets of the 2030 Agenda are integrated and indivisible, they are of a global nature and universally applicable to all countries, both developed and developing. They show a balance between the three dimensions of sustainable development, namely, the economic, social and environmental dimension. Plus, they ensure that none will be left behind" (André, 2018).

New international agreements have repeatedly pointed out the importance of a number of institutions -public, private and civil society- taking part in the promotion of sustainable development. Participation of workers and unions has been highlighted, especially in relation to the aims of achieving social sustainability. As stated by the United Nations, "Information, education and training on sustainability at all levels, including in the workplace, are key to strengthening the capacity of workers and trade unions to support sustainable development" (UN).

The Argentine trade union movement, in agreement with international trade unionism, is committed to the implementation and evaluation of compliance with the 2030 Agenda, with training, cooperation, participation and advocacy actions. Trade unions have been key actors in the construction of the SDGs, specifically in relation to the inclusion and implementation of sector-specific priorities such as promoting decent work, reducing inequality, achieving universal education and participation from civil society (González, 2018). Since 2006, the IPLIDO has developed its various action programs following this framework.

\section{The IPLIDO-UTHGRA: Strategies and Actions in Pursuit of Social Sustainability}

IPLIDO-UTHGRA was created on July 1st, 2006 under the premise that "true freedom is born from equal opportunities". The scope of the Institute has been to develop new programs and actions aimed at guaranteeing equal opportunities and equal treatment for all workers, men and women, adapting policies to the current situation and their needs. In the following pages, we will firstly introduce the features of the activity area represented by UTHGRA, which constitutes the main target population of the IPLIDO actions. Secondly, we will give an account of the main intervention and linking 
strategies carried out by the Institute with the State, the international community and civil society actors. Finally, we will develop some of its main achievements, within the aforementioned framework of the social sustainability dimension.

\subsection{Background, Goals and Action Programs}

Currently, UTHGRA represents more than 125.000 registered workers and serves more than 320.000 people (if the primary family group of incumbent members is included). Within the group of affiliates, four out of ten are women and six out of ten are under forty years old. The distribution by gender tends to be similar among the different age groups. Despite this, the percentage of women's affiliation in relation to men's slightly decreases as the age range increases: an average of 45\% in the range of 25-44 years old, $41 \%$ in the range of $45-60$ years old, and of $24 \%$ for those over sixty years old. The legal retirement age of female labor force explains this variation (sixty years for women vs. sixty-five years for males). In relation to workers' status, $78 \%$ of men are heads of household, while this proportion drops to $54 \%$ in the case of women. On the other hand, $50 \%$ of men provide -through their salary- the only income of the household, while this situation represents only a 34\% in the case of women.

This data set allows us to account for at least two issues: first, the importance of women participation, both in the activity area represented by the union and in the use of different social benefits provided by UTHGRA's medical insurance system (OSUTHGRA). Secondly, the persistence of gender inequalities in the sector, in line with the main issues that affect women in the workplace, such as the so-called "sticky floor" and the "glass ceiling" (Rojo Brizuela \& Tumini, 2008).

Based on this diagnosis, in 2006 the union decided to replace the Women's Department with the IPLIDO, so as to establish a new approach for its intervention strategies. Thus, the IPLIDO emerged as a space that, from the union sphere, aims at guaranteeing equal opportunities for all people based on equal participation of men and women in the labor, economic, political, cultural and family environment. Its actions seek to generate a constant interaction between the public sector and the community in the promotion of rights and values in the trade union sphere and the community in general. Graciela Camaño, founder of the Institute and current National Deputy, mentioned in this regard: "It is a challenge for unionized women to train themselves and gain participation. Permanent dialogue and active participation in workplaces, in the management committe, in the joint commissions of union representatives and management committees; contributing ideas, enriching the content of the agreements and, fundamentally, contributing a women's approach in the world of labor are truly the real tools that our women workers possess to achieve the integration and equality of conditions that we favor and desire".

Equality of opportunities is a commitment of global dimension applicable both to the States and their inhabitants and to international relations. The Declarations on Human Rights and the Conferences of the United Nations are significant evidences of the global nature of this principle. In a wide sense, equality of opportunity is a way of conceiving social justice that understands that a system is socially just when people have the same potential for accessing social welfare and enjoying the same civil and political rights (Roemer, 1998). This approach poses that the possibilities to occupy the different social 
positions should be distributed equally among all people, on a competitive basis established without substantial differences, such as economic resources or status. However, at the same time, this approach presupposes an equal allocation of rights and equal distribution rules (Paya, 2000).

Based on this, the Institute has been working for more than a decade on building equal participation status for men and women, as well as strengthening the role of women in the labor sphere, its impact on union activity and on the activity area. To this end, the IPLIDO has established four lines of work aimed at strengthening and expanding the participation of women in the union, promoting social justice without gender distinction, building bridges between the organization and the community and circulating relevant information linked to equality of opportunities.

One of the first major actions carried out by IPLIDO was the First National Survey of Gastronomic and Hotel Workers [ENATHGRA]. The data obtained in this survey (carried out in 2008) allowed the Institute to have a thorough knowledge about the existing issues and demands among the affiliates and became an essential tool for the design of policies, initiatives and actions. The dimensions surveyed included contractual and labor insertion; labor organization; training; working conditions and environment; work environment; union relations; medical insurance benefits; compensations and socio-demographic characteristics.

Based on this information, the ten current Work Programs were consolidated. They are: Living with Values, Addiction, Teenage Pregnancy, Cardiovascular Risk Factors, Guidelines for Parents, Breastfeeding, Resilience, Human Trafficking, Family Violence and Grooming.

In 2010, after four years of work and as a response to the needs identified throughout the country, the Institute amended its Statute in order to create permanent local branch offices in several districts of the Union. In turn, the role of Executive Secretary was created to designate the person in charge of coordinating all the actions, programs and initiatives that are carried out at the federal level. This change and growth in the structure of the IPLIDO meant an important step forward in both qualitative and quantitative terms. It resulted in the creation of fifty-three permanent local branches, distributed throughout the country, and operating within UTHGRA Sectional Offices. Federalization also triggered an expansion of the territorialization of actions and ensured the distribution of new information that was later used as input for the design of new institutional strategies and lines of work, some of which will be discussed below.

\subsection{Networking as a premise: Union, Community and State}

Working with affiliates and the community as a whole is one of the central strategies of the Institute. In this case, although the Head Office outlines the main issues to be addressed, the branch offices are the motor for actions to be carried out as well as the trigger for strategies they consider necessary based on their local realities. To this end, IPLIDO articulates its actions with other programs and areas within the Union and, at the same time, the branch offices build their own networks at the local level. Throughout the last years, they have accomplished:

- 11 National Meetings of Working Women

- 9 National Awareness Campaigns for the "International Day for the Elimination of 
Violence against Women" - November 25th.

- 3 National Awareness Campaigns on Human Trafficking for the "International Day Against Human Trafficking" - July 30th.

- 20 Awareness Workshops on Violence Against Women carried out in conjunction with the National Institute for Women (INAM)

- 20 Awareness Workshops on Problematic Consumption of Psychoactive Substances, carried out in conjunction with the Secretariat of Integrated Policies on Drugs of the Argentine Nation (SEDRONAR)

- 1 Course of Prevention of Addictions - SEDRONAR

- 10 Grooming Awareness Workshops

Some of these activities are conducted by delegates of the union and aimed at them while others are aimed at the community of members and the community in general. These actions have an strong relation with network work carried out by the Institute together with institutions and social, political, academic, business and trade union organizations. Some of the most important ones include:

Casa del Encuentro Foundation; Vínculos en Red organization, dedicated to reporting cases of human trafficking, victims assistance and case training; the Foundation for Studies and Research of Women [FEIM]; the Argentine Association of Women of Legal Careers [AAMCJ]; the Center for Studies in Drug Addiction and Sociopathies [CEDROS] of the ISALUD University; the Pastoral Episcopal Church; the Argentine Union of Rural Workers and Stevedores [UATRE]; and the Women in Equality Foundation [MEI], among others. Also, since 2008, IPLIDO participates in the Provincial Network for Women Free of Gender Violence.

The work experience with the National Institute of Women (INAM) is a good example of the kind of joint work conducted in the last years. The INAM is the body for gender equality in Argentina. It was created in 2017 as a continuation of the National Council of Women, established in 1992. It is a decentralized entity within the jurisdiction of the Ministry of Social Development of the Nation. Since 2016, IPLIDO has carried out several exchange actions with the INAM. Among them, joint training sessions attended by delegates from UTHGRA and the community have been key. Likewise, the IPLIDO in coordination with other areas of the union- provides study scholarships so that women who have been or are victims of gender violence can be trained in the Trade Union Professional Training Institute, thus improving their chances of entering the labor market.

A similar work is carried out with the Secretariat of Integral Policies on Drugs of the Argentine Nation [SEDRONAR]. In this case, in addition to the exchange of data and diagnoses on the topic of addiction and problematic consumption in the activity area represented by the union, both institutions signed a cooperation agreement. Its main objective is to organize workshops based on these subjects to be conducted by SEDRONAR and attended by the UTHGRA affiliates and the local community. The UTHGRA also provides a physical space in its medical insurance offices for the operation of SEDRONAR service offices.

In this sense, IPLIDO aims at making a contribution to the community as well as to the various organizations that have an influence in the development of public policies, while 
being nourished by this joint construction as a mechanism for social transformation towards achieving equal opportunities.

\subsection{Public policies and international guidelines: the commitment to sustainable development}

The path set by IPLIDO is nurtured and oriented by the guidelines established in national and international policy, which the Institute in turn helps to design. In this regard, we consider it relevant to point out two participation areas due to the significance they have at a local and international level.

The first participation space is the Commission on the Status of Women of the United Nations (CSW-UN), in which the IPLIDO participates since 2014. In this case, the Institute participates through the representation of its Executive Secretary and of the region's leaders. The election of those who travel to the New York City annual meeting is done based on the strategic lines that are addressed in that meeting and the relationship that this has with their regional work. Hence, strategically, IPLIDO representatives seek to integrate their worklines into the specific work themes of the Institute in order to generate a significant contribution.

The construction process prior to the annual meeting shines some light on these spaces relevance. In this case, the Argentine delegation (where IPLIDO participates) builds a discussion agenda throughout the year to later present at the CSW. This agenda is debated and agreed upon in working groups composed of local actors that represent public institutions, civil society and the private sector. The IPLIDO takes part in two of these groups: the Trade Union and Gender Table and the Open Government Roundtable. The local discussion intends to advance in the design of public policies, framed within the goals set by the national reference bodies, in this case, the United Nations.

This work is articulated with the participation of IPLIDO in the Tripartite Commission for Equality of Opportunities (CTIO-Gender) of the National Ministry of Production and Labor. It is a space for tripartite social dialogue and the search for consensus, composed of representatives of the government, trade union and business sectors. IPLIDO participates in two subcommittees: Equal Participation of Women and Men in the Workplace and Work and Family Reconciliation within the Framework of Citizen Social Co-responsibility.

Some of the most relevant actions carried out in this area have been the fight for compliance with the Law of Quota, for which the creation of a complementary rule to Decree 514/2003 has been promoted, under a Ministry of Labor resolution; and the design of bills in line with the standards established by the International Labor Organization (ILO), such as the extension of paternity leave and the license for gender violence that will become parliamentary during this year.

\subsection{Some results}

Since its creation, IPLIDO has achieved important advances in both quantitative and qualitative terms. In the first place, federalization of actions through the opening of permanent delegations in branch offices throughout the country has allowed the scope of its activities to increase steadily. This growth also meant the need to outline new 
strategies to adapt the programs of the Institution to the local realities and idiosyncrasies, while also maintaining a unified discourse throughout the country. In this way, the building of networks, alliances and cooperation agreements has surfaced as a nodal strategy. Linking with other institutions allows IPLIDO to join efforts towards a common goal, to share experiences, work materials and thus to strengthen work results. Secondly, the growth achieved in the participation of women in the union and, fundamentally, in the areas of representation and decision-making is to be highlighted. Within the framework of the IPLIDO, the creation of the post of Region Leaders has empowered women leaders to articulate, organize activities and build links in their respective regions within UTHGRA and outward with the community in which they work and live. The IPLIDO representatives are also all UTHGRA leaders. Some of them are General Secretaries, other Training Secretaries, Assistant Secretaries or delegates of establishments. Occupying these positions has also allowed them to build an key block within the National Congress of the Union that takes place every year in May in the city of Mar del Plata.

Likewise, IPLIDO actions have had an important impact in terms of women participation within the framework of the union's organizational structure. When comparing the data for the 2005-2009 period (when IPLIDO was founded) with the 2017-2021 period (that is, the recently elected lists period), some concnlusions can be reached:

- In the National Secretariat, women increased their participation from $30 \%$ of the positions to $36.6 \%$

- In the Sectional Commissions the increase was from $32.11 \%$ to $38.86 \%$

- In the case of spokepeople (where political interference and power of decision is lower than in other positions) the percentages remained stable at around $40 \%$ and,

- In the case of the Congresswomen, the increase was from $17.44 \%$ to $36.6 \%$.

On average, this increase in female participation implies a step from $32.10 \%$ to $38.6 \%$ in the total of the organizational structure. It should also be noted that executive and congressional offices -where the highest increases were recorded- are the most relevant, as they represent the areas of power and decision in the union organization.

\section{Conclusions}

One of the central and necessary elements to achieve sustainable development is taking into account the complexity of the world in which we live and, from there, the necessary integration of its environmental, social, cultural and economic dimensions to implement appropriate strategies for achieving it. Among these, the "social dimension" becomes a fundamental part of intervention in order to guarantee the commitment to social inclusion, the fight against the multiple forms of exclusion and discrimination and encourage the participation of large majorities in public affairs. In this sense, as expressed by Ines Omann and Joachim Spangenberg (2002)

“... social sustainability comprises every citizen's right to actively participate in his/her society as an essential element. The precondition for this is the access to the respective societies' resources, including a variety of aspects: physical access demands the existence of the appropriate technical, social and institutional infrastructure, legal access calls for 
the right to make use of it, economic access means the affordability of using it, educational access is supported by appropriate (life-long) learning opportunities, and participatory access stresses the influence on the evolution of such infrastructures" (p. 5). In this framework, IPLIDO institutional model is based on a strategy that intends to intertwine the union, community and public spheres in order to generate more equal opportunities for men and women. To achieve this, it has compromised to a work that addresses the heterogeneity of territorial issues from a solidary and cooperative logic with public institutions, international organizations and civil society as a whole.

As we have intended to show in this paper, the strategies adopted at the Institute have allowed for the promotion and increase of women participation in union life, as well as strengthening networking among different agencies, building institutional articulations and developing actions towards the community. All this through a constant exchange with the agencies responsible for the design and implementation of public policies, both nationally and internationally.

Although there are still many challenges to be faced -in a changing and complex global and national context- we are interested in highlighting the fundamental role played by trade union organizations on the road to social justice. We would like to highlight the social dimension of sustainability, especially regarding the strengthening of the participation and network building processes, as a determining factor in creating paths that improve people's quality of life and promote long-term sustainable development.

\section{References}

André, M. H. (2018). La Agenda 2030 para el desarrollo sostenible: oportunidades y desafíos para la acción sindical. In M. c. González (Ed.), La perspectiva sindical sobre los Objetivos de Desarrollo Sostenible: Argentina en la Agenda 2030 (pp. 35-43). Ciudad Autónoma de Buenos Aires: Aulas y Andamios.

Foladori, G. (2002). Avances y límites de la sustentabilidad social. Economía, Sociedad y Territorio, III(12), 621637.

Gomaa, B., \& Sakr, N. (2015). Social Sustainability; Maintenance of Socio-Cultural Characteristics: A Case Study of El-Raml Station. European Journal of Sustainable Development, 4(2), 203-212.

González, M. C. (2018). La perspectiva sindical sobre los objetivos de desarrollo sostenible: Argentina en la Agenda 2030. Ciudad Autónoma de Buenos Aires: Aulas y Andamios.

Károly, K. (2011). Rise and fall of the concept sustainability. Journal of Environmental Sustainability, 1(1), 1-12.

Löf, R.-M. (2018). What is sustainable development at University of Gävle?

McKenzie, S. (2004). Social sustainability: towards some definitions. Working Paper Series. Magill, South Australia.

Omann, I., \& Spangenberg, J. (2002). Assessing social sustainability. Paper presented at the Biennial Conference of the International Society for Ecological Economics.

Paya, I. (2000). La igualdad de oportunidades como criterio de lo justo. A Parte Rei Revista de Filosofía(10), 117.

Roemer, J. (1998). Igualdad de oportunidades. Isegoria(18), 71-87.

Rojo Brizuela, S., \& Tumini, L. (2008). Inequidades de género en el mercado de trabajo de la Argentina: las brechas salariales. Revista de trabajo, 4(6), 53-70.

Sachs, I. (1999). Social sustainability and whole development: exploring the dimension of Sustainable Development. In E. Becker \& T. Jahn (Eds.), Sustainability and the Social Sciences (pp. 25-36). New York: UNESCO \& ISOE.

Spangenberg, J., Pfahl, S., \& Deller, K. (2002). Towards indicators for institutional sustainability: lessons from an analysis of Agenda 21. Ecological indicators, 2(1-2), 61-77.

Vallance, S., Perkins, H., \& Dixon, J. (2011). What is social sustainability? A clarification of concepts. Geoforum, 42(3), 342-348. 